\title{
Behavior of juvenile bluefish Pomatomus saltatrix in vertical thermal gradients: influence of season, temperature acclimation and food
}

\author{
Bori L. Olla ${ }^{1}$, Anne L. Studholme ${ }^{2}$ \& Allen J. Bejda ${ }^{2}$ \\ ${ }^{1}$ Cooperative Institute for Marine Resources Studies, Northwest and Alaska Fisheries Center, National Marine Fisheries \\ Service, Hatfield Marine Science Center, Newport, Oregon 97365, USA \\ 2 US Department of Commerce, National Marine Fisheries Service, Northeast Fisheries Center, Sandy Hook Laboratory, \\ Highlands, New Jersey 07732, USA
}

\begin{abstract}
Behavioral responses of juvenile bluefish Pomatomus saltatrix L. exposed to cold water in a vertical thermal gradient were measured under controlled laboratory conditions. The temperature regime was similar to conditions that these fish encounter in their inshore and estuarine habitats along the Middle Atlantic coast. Measures included activity, schooling, position with respect to depth and temperature, and feeding. Bluefish, acclimated to 20 or $14{ }^{\circ} \mathrm{C}$, avoided cold water as it was introduced into the experimental aquarium by initially increasing swimming speed and shifting their distribution upward in the water column. Fish with a similar thermal history were distributed into progressively colder water from August through November, reflecting a predisposition for lower temperatures. This change in behavioral response to temperature coincided with this species' southerly fall migration. When food was presented at potentially debilitating temperatures which were normally avoided, motivation to feed modified their avoidance response, with the fish entering these temperatures and successfully feeding. Results are discussed in relation to natural patterns of migration and distribution.
\end{abstract}

\section{INTRODUCTION}

Temperature plays a crucial role in almost all aspects of a fish's biochemistry, physiology and behavior. Since the vast majority of species do not have the capability to regulate body temperature, their ability to avoid or select environmental temperature, i.e. to thermoregulate behaviorally (Rozin \& Meyer 1961. Neill et al. 1972, Neill \& Magnuson 1974) is one of the more critical components of their behavioral repertoire. In general, there exists a range of temperature below or above which a given species cannot survive (Fry 1947). Once these limits are determined, predictions as to where a species will not be found can be made with a high degree of confidence. Far less predictable is where, within these thermal limits, a species may be distributed. While thermal history has long been recognized as influencing thermal responses in fish (Fry 1967, 1971, Brett 1970, Fry \& Hochachka 1970), in terms of thermal distribution, a number of other factors, both biotic and abiotic, have also been found to play an important role. These include season (Sullivan \& Fisher 1953, Fry \& Hochachka 1970, Olla et al. 1980), food availability (Neill \& Magnuson 1974), nutritional state (Javaid \& Anderson 1967, Stuntz \& Magnuson 1976), competition and/or predation (Brandt et al. 1980, Crowder \& Magnuson 1982), time of day (Medvick \& Miller 1979), salinity (Garside \& Morrison 1977), age (McCauley \& Read 1973, Kwain \& McCauley 1978), social factors (Medvick et al. 1981), pathological condition (Reynolds et al. 1976) and habitat requirements (Olla et al. 1978, 1980).

In this work, we have examined the influence of 3 of these factors - thermal acclimation, season and food availability - on the distribution of juvenile bluefish Pomatomus saltatrix in vertical thermal gradients. Both adults and juveniles of this species naturally encounter vertical as well as horizontal thermal gradients along the Atlantic coast (Norcross et al. 1974, Magnuson et al. 1980). In the New York Bight, the area in which the fish used in this study were captured, a large cell of cold water persists through all or part of the year (Ketchum \& Corwin 1964, Ingham et al. 1982) with cell 
temperatures in summer often 10 to $12 \mathrm{C}^{\circ}$ colder than surface waters. The distribution of water associated with this cell depends upon both meteorological and hydrographic conditions (Ingham et al. 1982) so that fish, even those occurring inshore and in estuaries, can be subjected to large fluctuations in temperature over a short period of time.

Previous studies with both adult and juvenile bluefish have suggested that this species is capable of behavioral thermoregulation (Olla \& Studholme 1971, 1976, 1978, Olla et al. 1975, Olla 1977). Under homeothermal conditions in which temperature departed upward or downward from acclimation, swimming speed increased, and at thermal extremes remained elevated until temperature returned to less stressful levels. Persistence of high activity was interpreted as reflecting thermal avoidance, but in the absence of a gradient, this could only remain conjectural.

In this paper we have examined the behavior and distribution of groups of juvenile bluefish exposed to vertical thermal gradients under controlled laboratory conditions. These gradients were designed to span the range of temperatures that these fish might encounter, either from the rapid inshore intrusion of cold water during the summer or during their southerly migration in the fall, to measure their immediate and short-term responses to these changes. To determine whether season affected their responses, we compared their behavior in similar thermal gradients before and during the time of their fall migration and since these fish naturally encounter lower temperatures during late fall, we also examined the effect of thermal acclimation on distribution. Since food acquisition is especially critical for rapidly growing juveniles, we examined the capability of fish which were highly motivated to feed to acquire food at temperatures which were potentially debilitating, determining the extent to which this would modify thermal distribution. To relate these responses to the physiological capability of the fish, we also measured equilibrium loss to rapid downward changes in temperature.

\section{MATERIALS AND METHODS}

Juvenile bluefish Pomatomus saltatrix (15.5 to $21.3 \mathrm{~cm}$ total length, TL) were captured throughout summer and fall by hook and line or seine net in Sandy Hook Bay, New Jersey, at 17.5 to $21.0^{\circ} \mathrm{C}$. Prior to experiments, the fish were held in 3.8 or $6.7 \mathrm{kl}$ seawater aquaria under simulated seasonal changes in photoperiod and at temperatures adjusted to meet experimental requirements (Table 1). Seawater quality was maintained by recirculation through a filtrant composed of sand, gravel and oyster shell with small amounts of new seawater added periodically. Salinity averaged $25 \%$; pH, 7.6; dissolved oxygen $7.0 \mathrm{mg} \mathrm{l}^{-1}$. In both holding and experimental aquaria, fish were fed to satiation on live killifish Fundulus heteroclitus or small $(\sim 0.5 \mathrm{~g})$ pieces of surf clam Spisula solidissima at 2 to $4 \mathrm{~d}$ intervals.

Equilibrium loss experiments. Juvenile bluefish (16.8 to $21.2 \mathrm{~cm} \mathrm{TL}$ ) acclimated to $19.8^{\circ} \mathrm{C}\left( \pm 1.5 \mathrm{C}^{\circ}\right.$ ) or $14.1{ }^{\circ} \mathrm{C}\left(+1.3 \mathrm{C}^{\circ} ;-1.2 \mathrm{C}^{\circ}\right)$ (Table 1) were transferred individually from holding aquaria to a $360 \mathrm{l}$ aquarium $(1.2 \times 0.6 \times 0.5 \mathrm{~m})$ in which seawater had been chilled to the selected test temperature $\left( \pm 0.2 \mathrm{C}^{\circ}\right)$. Fish acclimated to $19.8^{\circ} \mathrm{C}$ were transferred to $1,3,5,7,9,11$ or $20^{\circ} \mathrm{C}$ with 10 replicates at each temperature; fish acclimated to $14.1^{\circ} \mathrm{C}$ were transferred to $1,3,5,7,9$, or $14^{\circ} \mathrm{C}$ with 5 replicates at each. A closed circuit video system with recorder (see below) was used to record responses with subsequent examination of the videotape made to determine time to loss of orientation (first collision with the aquarium wall), equilibrium and movement (motionless on the aquarium bottom for $>30$ s) (Table 2).

Experimental aquarium for thermal gradient and feeding experiments. All experiments were conducted in a $1.9 \mathrm{kl}$ fiberglass aquarium $(2.48 \mathrm{~m}$ length $\times 0.88 \mathrm{~m}$ width $\times 0.96 \mathrm{~m}$ depth) with a single viewing window $(2.29 \times 0.81 \mathrm{~m})$. In the absence of a thermal gradient, filtered seawater was pumped at a rate of 1.5 to $1.9 \mathrm{l} \mathrm{s}^{-1}$ upwards through the bottom of the aquarium through a $0.5 \mathrm{~cm}$ thick fiberglass panel that was perforated with rows of $0.6 \mathrm{~cm}$ diameter holes spaced every $2 \mathrm{~cm}$. This allowed even distribution of incoming water across the bottom of the aquarium and insured that in establishing a thermal gradient there would be an even distribution of water at a given depth (confirmed by dye tests). As incoming water rose toward the surface, 2 overflow surface outlets at opposite ends of the aquarium diverted the flow during the gradient tests to a drain and at other times to a biological filter through which the water would pass before returning to the bottom of the aquarium. When establishing a vertical gradient, chilled water $\left(\sim 0^{\circ} \mathrm{C}\right)$ was introduced for about 8 to $10 \mathrm{~min}$ through the perforated bottom, forcing surface water through the overflows out of the system, and when the desired thermal gradient was established, the inflow of chilled water was stopped. At the completion of the experiment, the cold water, about one-half the volume of the aquarium, was drained through the bottom to avoid subjecting the fish to low temperature; then seawater at the acclimation temperature was introduced and normal circulation resumed.

Temperature $\left( \pm 0.05 \mathrm{C}^{\circ}\right)$ within the aquarium was monitored continuously by 10 thermal probes each connected to a multichannel strip chart recorder. These 
Table 1. Pomatomus saltatrix. Summary of acclimation temperatures and experimental conditions for equilibrium loss, thermal gradient and feeding experiments for juveniles

\begin{tabular}{|c|c|c|c|c|c|c|c|c|}
\hline \multirow[b]{3}{*}{$\begin{array}{l}\text { Experimental } \\
\text { series }\end{array}$} & \multirow[b]{3}{*}{$\begin{array}{c}\text { Dates } \\
\text { (range) }\end{array}$} & \multirow{2}{*}{\multicolumn{3}{|c|}{ Experimental conditions }} & \multicolumn{4}{|c|}{ Acclimation temperatures } \\
\hline & & & & & \multicolumn{2}{|c|}{ Prior to 1 st experiment } & \multicolumn{2}{|c|}{ Between experiments } \\
\hline & & $\begin{array}{l}\text { Photo- } \\
\text { period } \\
\text { (h) }\end{array}$ & $\begin{array}{c}\text { Experi- } \\
\text { ments } \\
\text { (no) }\end{array}$ & $\begin{array}{l}\text { Size tested } \\
\mathrm{cm}(\mathrm{TL}) \\
\overline{\mathbf{x}} \\
\text { (range) }\end{array}$ & $\begin{array}{c}\text { Temp }\left({ }^{\circ} \mathrm{C}\right) \\
\text { (range) }\end{array}$ & $\begin{array}{l}\text { Days } \\
\text { held } \\
\text { (no) }\end{array}$ & $\begin{array}{c}\text { Temp } \\
\underset{\mathrm{x}}{ }\left({ }^{\circ} \mathrm{C}\right) \\
\text { (range) }\end{array}$ & $\begin{array}{l}\text { Days } \\
\text { held } \\
\text { (no) }\end{array}$ \\
\hline \multicolumn{9}{|l|}{ Equilibrium loss ${ }^{a}$} \\
\hline $20^{\circ}$ to $1-11^{\circ} \mathrm{C}$ & $10 / 7-12 / 2$ & $12.6-10.6$ & 60 & $\begin{array}{c}18.2 \\
(16.9-21.2)\end{array}$ & $\begin{array}{c}19.8 \\
( \pm 1.5)\end{array}$ & $42-72$ & & \\
\hline $14^{\circ}$ to $1-9^{\circ} \mathrm{C}$ & $1 / 14-27$ & $10.5-10.8$ & 25 & $\begin{array}{c}17.6 \\
(16.8-20.3)\end{array}$ & $\begin{array}{c}14.1^{b} \\
(+1.3 ;-1.2)\end{array}$ & $13-26$ & & \\
\hline \multicolumn{9}{|l|}{$\begin{array}{l}\text { Thermal gradient } \\
\text { experiments }\end{array}$} \\
\hline August & $8 / 21-24$ & 14.6 & 2 & $\begin{array}{c}16.3 \\
(15.5-17.8)\end{array}$ & $\begin{array}{c}20.6 \\
(+0.8 ;-1.0)\end{array}$ & 23 & $\begin{array}{c}20.7 \\
(+0.1 ;-0.3)\end{array}$ & 3 \\
\hline \multirow[t]{2}{*}{ Sep-Oct } & $9 / 12$ & 13.6 & 1 & $-^{c}$ & - & - & $\begin{array}{c}20.8 \\
(+1.2 ;-0.6)\end{array}$ & 19 \\
\hline & $10 / 6-18$ & $12.6-12.0$ & 2 & $\begin{array}{c}16.3 \\
(15.6-17.1)\end{array}$ & $\begin{array}{c}19.8 \\
(+1.0 ;-0.3)\end{array}$ & 56 & $\begin{array}{c}20.0 \\
(+0.3 ;-0.2)\end{array}$ & 12 \\
\hline \multirow[t]{2}{*}{ Nov } & $11 / 14-28$ & $11.0-10.6$ & 4 & $\begin{array}{c}19.0 \\
(16.7-21.0)\end{array}$ & $\begin{array}{c}20.2 \\
(+1.8 ;-1.9)\end{array}$ & 108 & $\begin{array}{c}20.0 \\
(+0.3 ;-0.2) \\
20.1 \\
(+0.3 ;-0.6)\end{array}$ & $\begin{array}{l}1 \\
3\end{array}$ \\
\hline & & & & & & & $\begin{array}{c}20.0 \\
(+0.4)\end{array}$ & 7 \\
\hline \multirow[t]{3}{*}{ Nov-Dec } & $11 / 17$ & 11.0 & 1 & $\begin{array}{c}17.3 \\
(15.8-19.6)\end{array}$ & $\begin{array}{l}14.5^{d} \\
( \pm 0.7)\end{array}$ & 11 & & \\
\hline & $11 / 27-12 / 1$ & $10.6-10.4$ & 2 & $\begin{array}{c}19.2 \\
(17.2-20.9)\end{array}$ & $\begin{array}{c}14.5 \\
(+0.4 ;-1.0)\end{array}$ & 21 & $\begin{array}{c}14.1 \\
(+0.2 ;-0.1)\end{array}$ & 3 \\
\hline & $12 / 5-19^{e}$ & $10.4-10.3$ & 2 & $\begin{array}{c}19.4 \\
(18.1-20.5)\end{array}$ & $\begin{array}{c}14.2 \\
( \pm 0.7)\end{array}$ & 29 & $\begin{array}{c}14.3 \\
(+0.6 ;-0.8)\end{array}$ & 13 \\
\hline \multicolumn{9}{|l|}{$\begin{array}{l}\text { Feeding } \\
\text { experiments }\end{array}$} \\
\hline \multirow[t]{6}{*}{ Jan-Mar } & $1 / 8-3 / 12$ & $10.5-12.7$ & 7 & $\begin{array}{c}19.8 \\
(16.9-21.3)\end{array}$ & $\begin{array}{c}20.0 \\
(+1.5 ;-2.0)\end{array}$ & 104 & $\begin{array}{c}20.2 \\
( \pm 0.2)\end{array}$ & 2 \\
\hline & & & & & & & $\begin{array}{c}20.1 \\
( \pm 0.2)\end{array}$ & 11 \\
\hline & $\cdot$ & & & & & & $\begin{array}{c}20.3 \\
(+1.5 ;-0.3)\end{array}$ & 10 \\
\hline & & & & & & & $\begin{array}{c}20.0 \\
(+0.2 ;-0.1)\end{array}$ & 8 \\
\hline & & & & & & & $\begin{array}{c}20.0 \\
( \pm 0.1)\end{array}$ & 2 \\
\hline & & & & & & & $\begin{array}{c}20.6 \\
(+1.7 ;-0.6)\end{array}$ & 24 \\
\hline \multicolumn{9}{|c|}{$\begin{array}{l}\text { a Fish tested at } 2 \mathrm{C}^{\circ} \text { temperature intervals, i.e. at } 1,3,5,7,9 \text { or } 11^{\circ} \mathrm{C} \\
b^{b} \text { Fish held at } 19.9^{\circ} \mathrm{C}\left( \pm 2.0 \mathrm{C}^{\circ}\right) \text { for } 117 \mathrm{~d} \text { prior to decrease }\left(0.55 \mathrm{C}^{\circ} \mathrm{d}^{-1}\right) \text { to } 14.1^{\circ} \mathrm{C} \\
\text { c Same group of fish as used in August experiments } \\
{ }^{d} \text { Fish held at } 16.6^{\circ} \mathrm{C}\left(+0.9 \mathrm{C}^{\circ},-0.4 \mathrm{C}^{\circ}\right) \text { for } 17 \mathrm{~d} \text { prior to decrease }\left(0.12 \mathrm{C}^{\circ} \mathrm{d}^{-1}\right) \text { to } 14.5^{\circ} \mathrm{C} \\
\text { e Experiment on } 12 / 19 \text { conducted under reduced daytime light levels }\end{array}$} \\
\hline
\end{tabular}


Table 2. Pomatomus saltatrix. Comparison of time to loss of orientation (wall collision), equilibrium (uncoordinated swimming) and movement (motionless $>30 \mathrm{~s}$ ) between juveniles transferred individually to low temperature from acclimation temperatures of $20^{\circ} \mathrm{C}(\mathrm{N}=10$ per temperature $)$ or $14^{\circ} \mathrm{C}(\mathrm{N}=5$ per temperature $)$

\begin{tabular}{|c|c|c|c|c|c|c|c|c|c|c|c|}
\hline \multirow{3}{*}{ Response } & \multicolumn{11}{|c|}{ Temperature $\left({ }^{\circ} \mathrm{C}\right)$} \\
\hline & \multicolumn{2}{|c|}{$1{ }^{\circ} \mathrm{C}$} & \multicolumn{2}{|c|}{$3^{\circ} \mathrm{C}$} & \multicolumn{2}{|c|}{$5^{\circ} \mathrm{C}$} & \multicolumn{2}{|c|}{$7^{\circ} \mathrm{C}$} & \multicolumn{2}{|c|}{$9^{\circ} \mathrm{C}$} & \multirow{2}{*}{$\begin{array}{l}11^{\circ} \mathrm{C} \\
20^{\circ} \mathrm{C}\end{array}$} \\
\hline & $20^{\circ} \mathrm{C}$ & $14^{\circ} \mathrm{C}$ & $20^{\circ} \mathrm{C}$ & $14^{\circ} \mathrm{C}$ & $20^{\circ} \mathrm{C}$ & $14^{\circ} \mathrm{C}$ & $20^{\circ} \mathrm{C}$ & $14^{\circ} \mathrm{C}$ & $20^{\circ} \mathrm{C}$ & $14^{\circ} \mathrm{C}$ & \\
\hline & \multicolumn{11}{|c|}{$\bar{x}(\min )$} \\
\hline Loss of orientation & 0.38 & 0.56 & 0.54 & 0.47 & 0.78 & 0.96 & 1.01 & 1.19 & 1.34 & $a$ & $4.03^{b}$ \\
\hline$t$ & \multicolumn{2}{|c|}{0.9483} & \multicolumn{2}{|c|}{0.4662} & \multicolumn{2}{|c|}{1.0352} & \multicolumn{2}{|c|}{0.6765} & & & \\
\hline $\mathrm{df}$ & \multicolumn{2}{|c|}{12} & \multicolumn{2}{|c|}{13} & \multicolumn{2}{|c|}{13} & \multicolumn{2}{|c|}{13} & & & \\
\hline $\mathrm{p}$ & \multicolumn{2}{|c|}{$>0.20$} & \multicolumn{2}{|c|}{$>0.50$} & \multicolumn{2}{|c|}{$>0.20$} & \multicolumn{2}{|c|}{$>0.50$} & & & \\
\hline Loss of equilibrium & 0.53 & 0.57 & 0.80 & 0.80 & 1.16 & 1.10 & 1.49 & 2.06 & 1.98 & $a$ & $8.15^{c}$ \\
\hline$t$ & \multicolumn{2}{|c|}{0.2741} & \multicolumn{2}{|c|}{0.0620} & \multicolumn{2}{|c|}{0.6037} & \multicolumn{2}{|c|}{2.4577} & & & \\
\hline df & \multicolumn{2}{|c|}{13} & \multirow{2}{*}{\multicolumn{2}{|c|}{$\begin{aligned} & 13 \\
> & 0.50\end{aligned}$}} & \multirow{2}{*}{\multicolumn{2}{|c|}{$\begin{aligned} & 13 \\
> & 0.50\end{aligned}$}} & \multirow{2}{*}{\multicolumn{2}{|c|}{$\begin{array}{c}13 \\
<0.05\end{array}$}} & & & \\
\hline $\mathrm{p}$ & \multicolumn{2}{|c|}{$>0.50$} & & & & & & & & & \\
\hline Loss of movement & 1.65 & 2.40 & 2.48 & 3.00 & 3.83 & 7.49 & 10.31 & $12.20^{d}$ & 14.50 & $a$ & $a$ \\
\hline$t$ & 1.9 & & 2.2 & & 2.3 & & & & & & \\
\hline $\mathrm{df}$ & & & & & & & & & & & \\
\hline $\mathrm{p}$ & & & $<0$ & & $<0$ & & & & & & \\
\hline a Not occurring in 30 & & & & & & & & & & & \\
\hline$b$ Occurring in 3 of & tested & & & & & & & & & & \\
\hline$c$ One fish swimming & up/tail & down & sture fo & $30 \mathrm{~min}$ & not occ & rring in & remainir & ng fish & & & \\
\hline $\begin{array}{l}\text { d Based on } 2 \text { fish; th } \\
\text { normal swimming; }\end{array}$ & $\begin{array}{l}\text { I } 3 \text { fist } \\
\text { ird swa }\end{array}$ & went $t$ & $\begin{array}{l}\text { ough a } \\
\text { th loss }\end{array}$ & $\begin{array}{l}\text { phase } \\
\text { f norma }\end{array}$ & $\begin{array}{l}\text { out we } \\
\text { coordin }\end{array}$ & $\begin{array}{l}\text { never } \\
\text { tion }\end{array}$ & notionle & ss for 3 & By 60 & $\operatorname{lin}, 2$ & resumed \\
\hline
\end{tabular}

probes, mounted vertically along the left rear corner of the aquarium, were positioned from $5 \mathrm{~cm}$ above the bottom to $4 \mathrm{~cm}$ below the surface, spaced 7 to $9 \mathrm{~cm}$ apart. During an experiment, probes were scanned sequentially every $20 \mathrm{~s}$ with temperatures interpolated across $2 \mathrm{~cm}$ intervals.

A closed circuit video recording system (Panasonic NV-8030 recorder and Sony video camera) was used to record each experiment beginning $10 \mathrm{~min}$ prior to a test until its completion.

Daytime lighting, provided by fluorescent lamps mounted above the aquarium, averaged $2 \times 10^{3}$ lux, as measured at the water surface, with low level night illumination of 0.5 lux provided by a $7.5 \mathrm{~W}$ incandescent bulb. As in the holding facilities, photoperiod was adjusted weekly to simulate natural seasonal changes.

The aquarium, filtration and lighting systems were screened by blinds and along with the thermal recorder and video camera, were housed in a sound-retardant, temperature-controlled room to reduce visual and acoustic interference.

Thermal gradient experiments. To insure that cessation in seawater circulation during gradient experiments would not affect the responses of the fish during an experiment, 2 sets of preliminary observations were made with 5 fish (15.6 to $17.1 \mathrm{~cm} \mathrm{TL}$ ) acclimated to $19.8^{\circ} \mathrm{C}$ : (1) with normal circulation of $20^{\circ} \mathrm{C}$ seawater and (2) as in a gradient experiment but with $20^{\circ} \mathrm{C}$ water introduced for $8 \mathrm{~min}$.
Fourteen experiments were conducted to measure responses of groups of 5 juvenile bluefish in vertical thermal gradients following acclimation to approximately 20 or $14^{\circ} \mathrm{C}$ under simulated seasonal changes in photoperiod (Table 1). Groups rather than isolates were used because of the natural schooling tendency of the fish and the adverse effect that separation from conspecifics could have on behavioral responses. Although there was some variability in depth of isotherms, the thermal gradients established in each experiment were generally similar, with the upper portions of the water column remaining at or within 2 to $3 \mathrm{C}^{\circ}$ of the acclimation temperature and separated from colder water in the lower half by a thin stratum of water in which temperature decreased very rapidly over a short distance; for the $20^{\circ} \mathrm{C}$ experiments from 17 to $13^{\circ} \mathrm{C}\left(\overline{\mathrm{x}}=0.5 \mathrm{C}^{\circ} \mathrm{cm}^{-1}\right)$; for $14^{\circ} \mathrm{C}$ experiments from 12 to $10^{\circ} \mathrm{C}\left(\overline{\mathrm{x}}=0.6 \mathrm{C}^{\circ} \mathrm{cm}^{-1}\right)$. Fish were observed for 10 min prior to and for $65 \mathrm{~min}$ following cold water introduction. Fish were then either removed or held until the next experiment (Table 1).

Feeding in a thermal gradient. Seven feeding experiments were conducted with the same group of 5 bluefish acclimated to $20.0^{\circ} \mathrm{C}\left(+1.5 \mathrm{C}^{\circ} ;-2.0 \mathrm{C}^{\circ}\right)$ (Table 1) in which, following the establishment of a vertical gradient, food was available only at lower temperatures in the lower half of the aquarium. Procedures for establishing gradients in these experiments were as described above except that occasionally small 
amounts of cold water were introduced to maintain temperatures from about 1 to $14^{\circ} \mathrm{C}$ in the lower half of the water column where food was available. This resulted in a gradual lowering of the temperature in the upper half of the aquarium during the course of the experiments.

For all feedings, small ( $\sim 0.5 \mathrm{~g} ; 1.0$ to $1.5 \mathrm{~mm})$ pieces of surf clam Spisula solidissima were introduced, one piece at a time, through a $22 \mathrm{~mm}$ diameter opaque tube mounted at the rear of the aquarium and extending from several $\mathrm{cm}$ above the top to $36 \mathrm{~cm}$ below the surface so that food was available only in the lower $44 \mathrm{~cm}$ of the aquarium. Temperatures at the feeding tube opening ranged from 9.7 to $14.6^{\circ} \mathrm{C}$ decreasing to as low as 1.2 to $5.5^{\circ} \mathrm{C}, 5 \mathrm{~cm}$ above the bottom. Food was introduced once cold water introduction ceased and the gradients stabilized which usually took about $16 \mathrm{~min}$. Feeding was continued until the fish no longer attempted an ingestion, with each experiment lasting approximately $35 \mathrm{~min}$. At the end of an experiment, $20^{\circ} \mathrm{C}$ water was introduced and the fish held in the experimental aquarium until the next experiment (Table 1). To condition the fish to feed readily in the experimental system, they were fed 6 times prior to the first experiment and then 1 to 3 times between each experiment $(N=13)$ to insure that feeding responses and motivation had not been affected. Comparison of attempts to feed and ingestions were made between 9 feedings at $20^{\circ} \mathrm{C}$ and the 7 gradient tests on the basis of the first 10 introductions of food since motivation was consistently high for this period under homeothermal conditions.

Behavioral analyses. Videotapes were viewed to determine the position $( \pm 0.5 \mathrm{~cm})$ of each fish every $20 \mathrm{~s}$ as measured from the tip of the snout to the bottom of the aquarium. The vertical distribution from bottom to surface in $2-\mathrm{cm}$ intervals was summed for all fish over 5 min periods $(N=75)$ and correlated with temperature profiles from the strip chart recorder. Percent occurrence was calculated at each degree, e.g. 20, $19 \ldots 1^{\circ} \mathrm{C}$. Additional measures recorded at the same time and expressed as means for each 5 min interval, included swimming speed (time for a fish to swim $61 \mathrm{~cm})$ and interfish distance, i.e. the average linear distance $(\mathrm{cm})$ between fish estimated by:

Group length $(\mathrm{cm})-$ [number in group $\times$ mean fish length $(\mathrm{cm})]$

$$
\text { (number in group-1) }
$$

In instances where there is an overlap among fish, this is expressed as a negative distance (e.g. $-10 \mathrm{~cm}$ ).

For the gradient experiments, in addition to the $20 \mathrm{~s}$ distribution profiles, measurements were made of the duration and frequency with which each fish: (1) swam along the sharpest gradient, and (2) swam into cold water below this gradient $\left(<12^{\circ} \mathrm{C}\right.$ for $20^{\circ} \mathrm{C}$ experi- ments; $<10^{\circ} \mathrm{C}$ for $14^{\circ} \mathrm{C}$ experiments). For feeding experiments, measurements were made of the temperatures at which fish attempted to feed or ingested food, the number of attempts and ingestions and duration of feeding excursions.

\section{RESULTS}

\section{Equilibrium loss experiments}

Fish acclimated to 20 or $14^{\circ} \mathrm{C}$ and then transferred to 1,3 or $5^{\circ} \mathrm{C}$ exhibited responses characteristic of thermal shock. Within 0.38 to $0.96 \mathrm{~min}$ fish were disoriented, swimming directly into the aquarium walls (Table 2). Within $1.16 \mathrm{~min}$, irrespective of acclimation temperature ( $\mathrm{P}>0.50, t$ test; Table 2$)$, there was a loss of motor coordination and equilibrium and the fish were unable to maintain their position in the water column.

When test temperatures reached $7^{\circ} \mathrm{C}$, slight differences appeared related to acclimation (Table 2). By $9^{\circ} \mathrm{C}$, fish acclimated to $14^{\circ} \mathrm{C}$ exhibited no behavioral manifestations of thermal shock while those acclimated to $20^{\circ} \mathrm{C}$ continued to be affected; by $11^{\circ} \mathrm{C}$. thermal shock responses were rarely observed (Table 2). Latencies for stress responses were shortest at the coldest temperatures, generally increasing as cold shock temperatures increased above $5^{\circ} \mathrm{C}$.

\section{Thermal gradient experiments}

At $20^{\circ} \mathrm{C}$, in the absence of any gradient, no differences were observed in activity, grouping or vertical distribution of juvenile bluefish between uninterrupted water circulation or when circulation was modified to simulate a gradient experiment. The fish swam at speeds averaging $9.4 \mathrm{~cm} \mathrm{~s}^{-1}$ in a loose aggregation with interfish distance averaging $+11 \mathrm{~cm}$. Vertical distribution was somewhat variable $(\bar{x}$ coefficient of variation $=23.9 \%$ ) as the fish ranged throughout the aquarium from surface to bottom.

\section{$20^{\circ} \mathrm{C}$ acclimation}

Nine experiments were conducted with fish caught during July and August at 19 and $20^{\circ} \mathrm{C}$ to determine responses to vertical thermal gradients (Table 1). Two experiments were conducted in August, 3 in September-October and 4 in November.

Activity, grouping and vertical distribution of the fish for 10 min prior to the introduction of cold water were similar to levels observed previously under the $20^{\circ} \mathrm{C}$ homeothermal regime. As cold water was intro- 
duced and gradually replaced the warm water in the lower half of the aquarium, swimming speed increased, averaging 18 to $26 \mathrm{~cm} \mathrm{~s}^{-1}$. The fish also were grouped more cohesively with average interfish distance decreasing to -8 to $-10 \mathrm{~cm}$, as they moved upward, avoiding cold water and swimming above the 12 to $14^{\circ} \mathrm{C}$ isotherms (Fig. 1, $2 \& 3$ ). After $15 \mathrm{~min}$ with the thermal profile stabilized and a sharp thermocline present at mid-depth in the aquarium, for the next $50 \mathrm{~min}$ the fish were distributed primarily in the upper half of the aquarium, swimming at gradually slower speeds until activity approached pretest levels (Fig. 1, $2 \& 3)$.

While generally avoiding low temperatures, typically individuals or groups of fish would swim downward into cold water, encountering temperatures ranging from 2.4 to $11.0^{\circ} \mathrm{C}$. After entering cold water, the fish would turn and swim rapidly upward, with bursts of speed reaching as high as $76 \mathrm{~cm} \mathrm{~s}^{-1}$, the fastest speed occurring after emergence from the lowest temperatures. The duration of these excursions ranged from 1.9 to $4.7 \mathrm{~s}$, the time depending on the speed and distance travelled.

Another typical behavior observed was fish swimming slowly downward until encountering the thin stratum of water representing the sharpest thermal gradient, i.e. 17 to $13^{\circ} \mathrm{C}$. Upon encountering the gradient, they would change course, and swim along or within this narrow band of cold water for $\sim 3$ to $5 \mathrm{~s}$ until reaching the end of the aquarium before turning and swimming upward into warmer water.

While these responses were characteristic of the fish in all experiments, there were obvious differences in temperature distribution which were correlated with season. In the August experiments, following stabilization of the gradients, the fish spent more than $95 \%$ of the time in the upper quarter of the aquarium above the $20^{\circ} \mathrm{C}$ isotherm (Fig. 1 \& 4). In September-October, the fish were distributed into colder water, spending only $63 \%$ of the time at $20^{\circ} \mathrm{C}$ (Fig. $2 \& 4$ ) and by November, the trend was even more pronounced with the fish swimming above the $20^{\circ} \mathrm{C}$ isotherm only $17 \%$ of the time and spending more than $30 \%$ below $18^{\circ} \mathrm{C}$ (Fig. $3 \& 4$ ).

The changing seasonal response to low temperature was also reflected by an increase in the frequency with which the fish made excursions into potentially debilitating temperatures as well as by an increase in swimming along or within the sharp midwater gradient. In August, each of these responses occurred infrequently $\left(\vec{x}=0.2 \mathrm{~min}^{-1}\right)$, increasing sharply in September-October $\left(\overline{\mathrm{x}}\right.$ excursions $=1.4 \mathrm{~min}^{-1} ; \overline{\mathrm{x}}$ gradient swimming $=1.5 \mathrm{~min}^{-1}$ ). By November, while excursions decreased $\left(\bar{x}=0.7 \mathrm{~min}^{-1}\right)$ the fish continued to be associated with the midwater gradient $\left(\overline{\mathrm{x}}=3.1 \mathrm{~min}^{-1}\right)$.

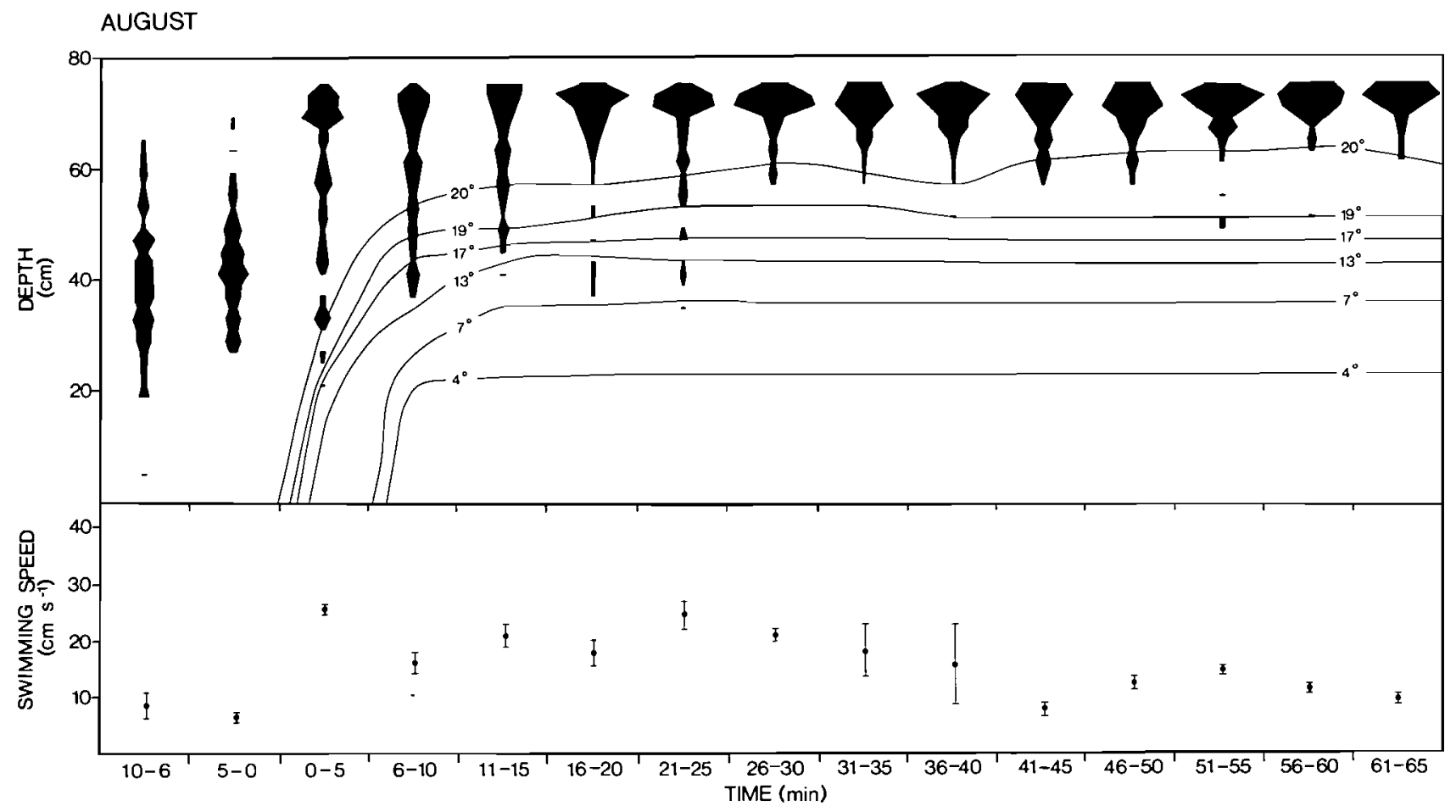

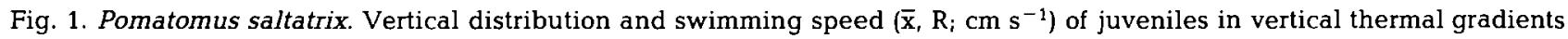
$\left({ }^{\circ} \mathrm{C}\right)$ in August following acclimation to $20^{\circ} \mathrm{C}$. Width of each distribution configuration represents number of fish at a given depth measured every $20 \mathrm{~s}$ within 5 min intervals. Data presented for $10 \mathrm{~min}$ prior to and 65 min following cold water introduction 


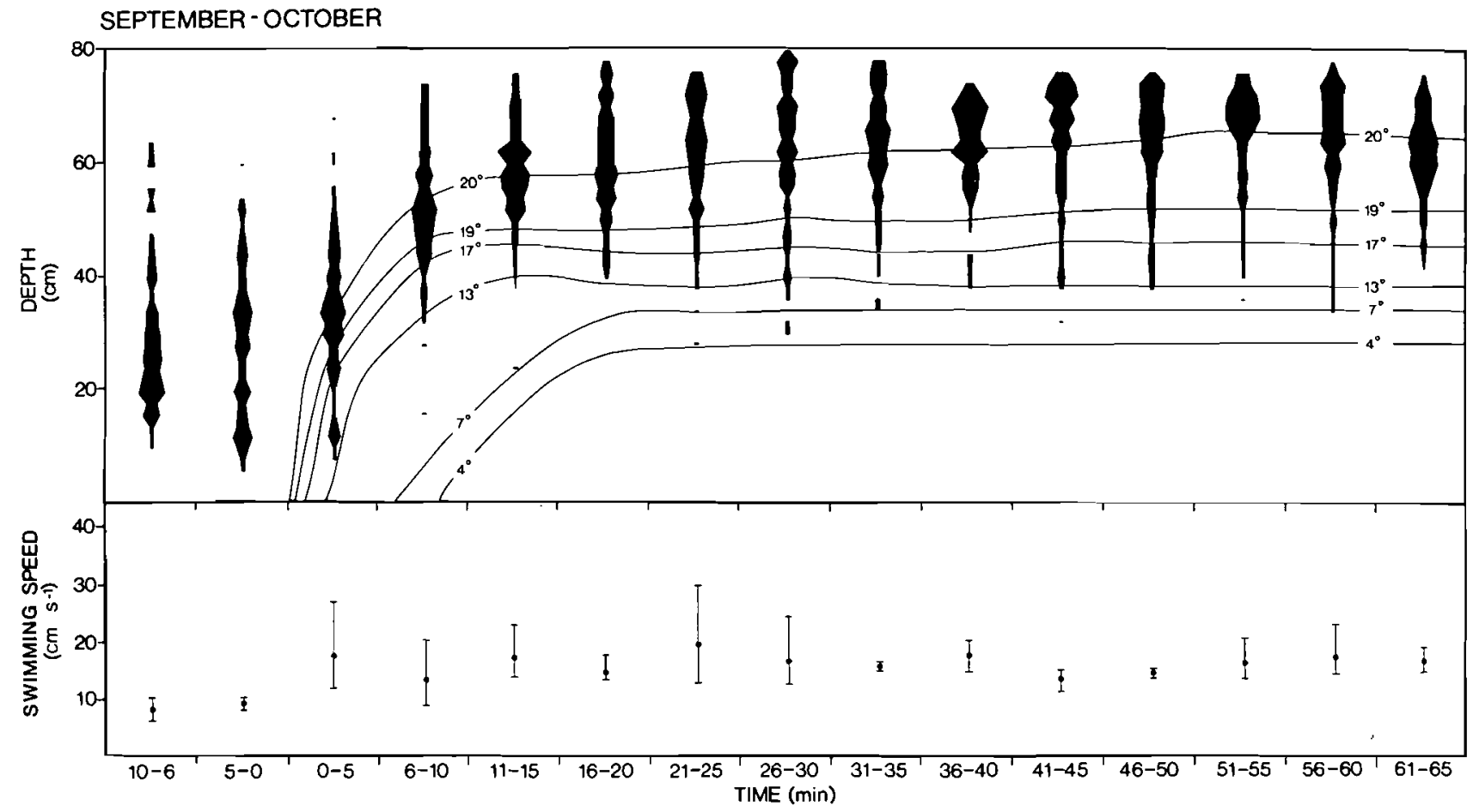

Fig. 2. Pomatomus saltatrix. Vertical distribution and swimming speed $\left(\bar{x}, R_{i} \mathrm{~cm} \mathrm{~s}^{-1}\right)$ of juveniles in vertical thermal gradients $\left({ }^{\circ} \mathrm{C}\right)$ in September-October following acclimation to $20^{\circ} \mathrm{C}$. Width of each distribution configuration represents number of fish at a given depth measured every $20 \mathrm{~s}$ within 5 min intervals. Data presented for $10 \mathrm{~min}$ prior to and 65 min following cold water introduction

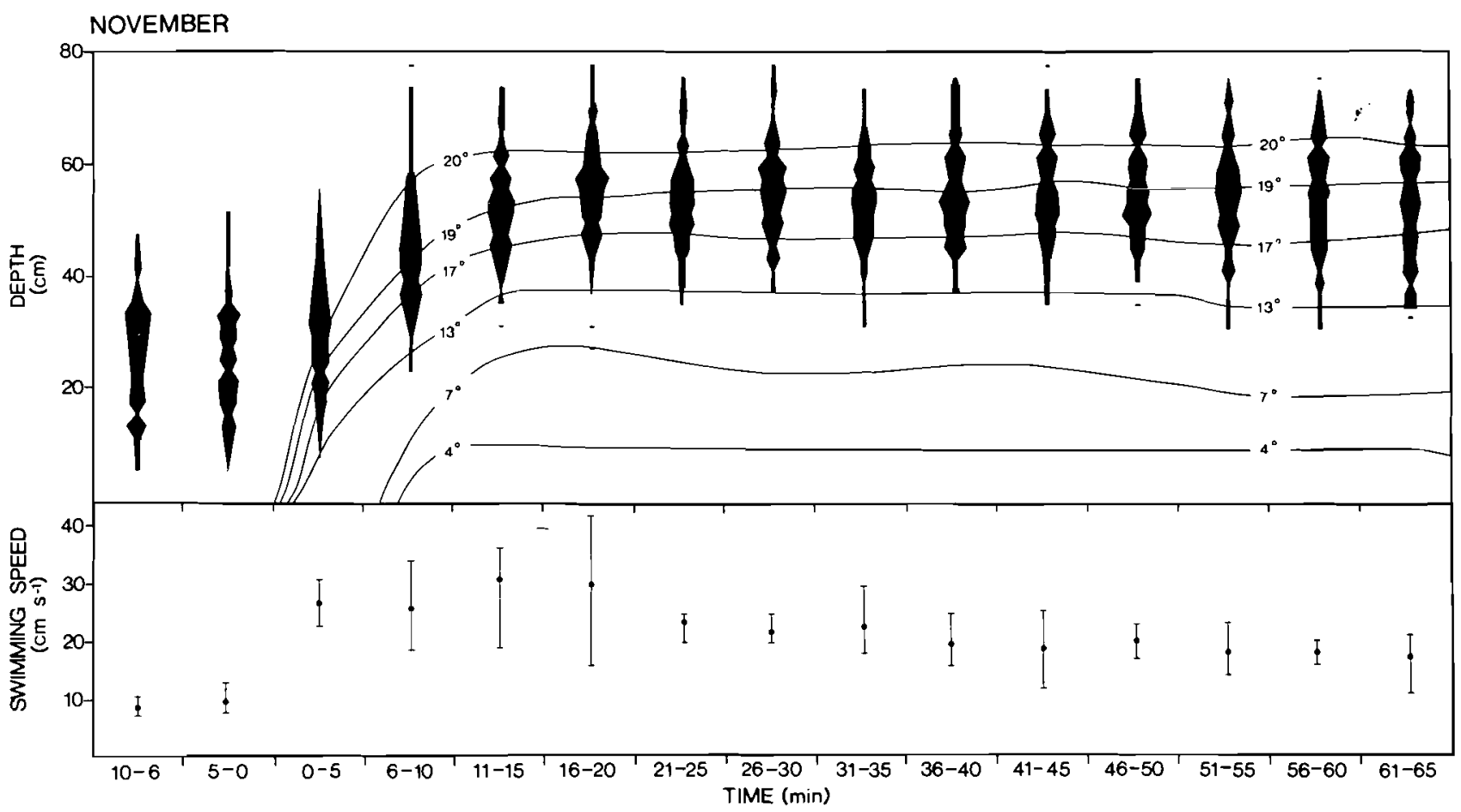

Fig. 3. Pomatomus saltatrix. Vertical distribution and swimming speed $\left(\overline{\mathbf{x}}, \mathrm{R}_{;} \mathrm{cm} \mathrm{s}^{-1}\right)$ of juveniles in vertical thermal gradients $\left({ }^{\circ} \mathrm{C}\right)$ in November following acclimation to $20^{\circ} \mathrm{C}$. Width of each distribution configuration represents number of fish at a given depth measured every $20 \mathrm{~s}$ within $5 \mathrm{~min}$ intervals. Data presented for $10 \mathrm{~min}$ prior to and 65 min following cold water introduction 


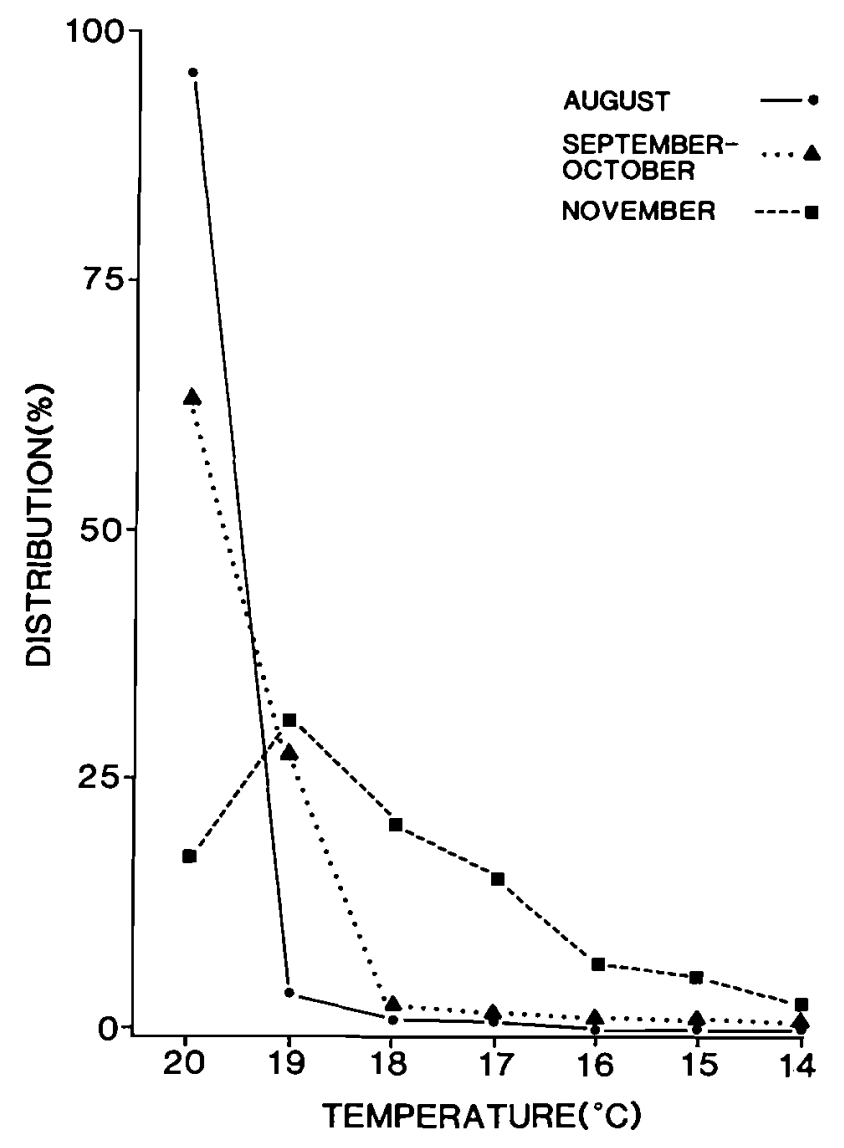

Fig. 4. Pomatomus saltatrix. Distribution (\% frequency of occurrence) of juveniles at 14 to $20^{\circ} \mathrm{C}$ following stabilization of vertical thermal gradients (16 through $65 \mathrm{~min}$ ) in August, September-October and November experiments following acclimation to $20^{\circ} \mathrm{C}$

$14^{\circ} \mathrm{C}$ acclimation

We next tested how changes in acclimation temperature would influence responses in a thermal gradient. Our choice of $14^{\circ} \mathrm{C}$ was based on the fact that this was several degrees above the level at which equilibrium loss occurred (Table 2) and yet was close to temperatures $\left(11\right.$ to $12^{\circ} \mathrm{C}$ ) at which both adult (Olla \& Studholme 1971) and juvenile bluefish (Olla 1977) had shown increases in activity indicative of avoidance.

Fish were captured in October at ambient temperatures 2 to $3 \mathrm{C}^{\circ}$ lower than the capture temperatures of fish used in all earlier experiments (Table 1). Five experiments were conducted in November-December to determine responses to thermal gradients in which $14^{\circ} \mathrm{C}$ was the highest temperature available.

Activity and grouping were similar to that observed at $20^{\circ} \mathrm{C}$ prior to cold water introduction with swimming speed averaging $10.4 \mathrm{~cm} \mathrm{~s}^{-1}$ and interfish distance $+3 \mathrm{~cm}$. Vertical distribution, however, was less variable as the fish swam lower in the water column, i.e. below $40 \mathrm{~cm}$ (Fig. 5). When cold water was introduced, as in earlier experiments, the fish showed avoidance, moving higher in the water column above the 6 to $9^{\circ} \mathrm{C}$ isotherms (Fig. 5) and grouping more cohesively, interfish distance decreasing to $-7 \mathrm{~cm}$. However, activity increased only slightly as the fish swam at speeds averaging $12.3 \mathrm{~cm} \mathrm{~s}^{-1}$ for a short time before returning to pretest levels (Fig. 5).

Following gradient stabilization the fish spent nearly $87 \%$ of the time at 12 and $13{ }^{\circ} \mathrm{C}$ as compared with less than $1 \%$ at these temperatures in the November experiments following $20^{\circ} \mathrm{C}$ acclimation. The synergistic effects of season and temperature resulted in lower thermal distribution.

As in all previous experiments, excursions were made downward into low temperatures with the frequency $\left(\overline{\mathrm{x}}=0.6 \mathrm{~min}^{-1}\right)$ only slightly lower than in the previous November experiments. Also, the fish frequently swam along or within the sharp midwater gradient $\left(12\right.$ to $\left.10^{\circ} \mathrm{C}_{i} \overline{\mathrm{x}}=2.1 \mathrm{~min}^{-1}\right)$.

\section{Feeding experiments in a thermal gradient \\ $20^{\circ} \mathrm{C}$ acclimation}

We next examined whether the motivation to feed would influence thermal distribution over and above that induced by seasonal and/or thermal history. To answer this question, a series of experiments was performed in which, following the establishment of a gradient, food was introduced into the lower half of the aquarium where temperatures were at levels that had been avoided previously. Experiments were conducted from January through March, with fish captured during August and September at 19 to $21^{\circ} \mathrm{C}$ (Table 1). Results are based on the means of 7 experiments.

Typically, at $20^{\circ} \mathrm{C}$ without a gradient, fish would respond to food by rapidly approaching and ingesting the piece before it reached the bottom. In 9 feedings, for the first 10 introductions, members of the group attempted to feed on $99 \%$ of the pieces introduced ( $N=90$ ), with ingestion occurring $100 \%$ of the time.

As in earlier experiments, once a gradient was established, the fish moved upward, avoiding cold water. When food was introduced fish had to swim down into cold water to feed. In contrast to feeding when the aquarium was homeothermal, attempts to feed on the first 10 introductions ( $N=70$ ) were made only $53 \%$ of the time. Of these attempts, $57 \%$ resulted in completed ingestions. Since by the time a fish sighted and approached food, it had sunk towards the bottom where temperatures were lower, over $78 \%$ of the attempts $(\mathrm{N}=29)$ were made at temperatures of 1 to $6^{\circ} \mathrm{C}$ (Fig. $6 \mathrm{~A}$ ). Of these feeding attempts, $52 \%$ 


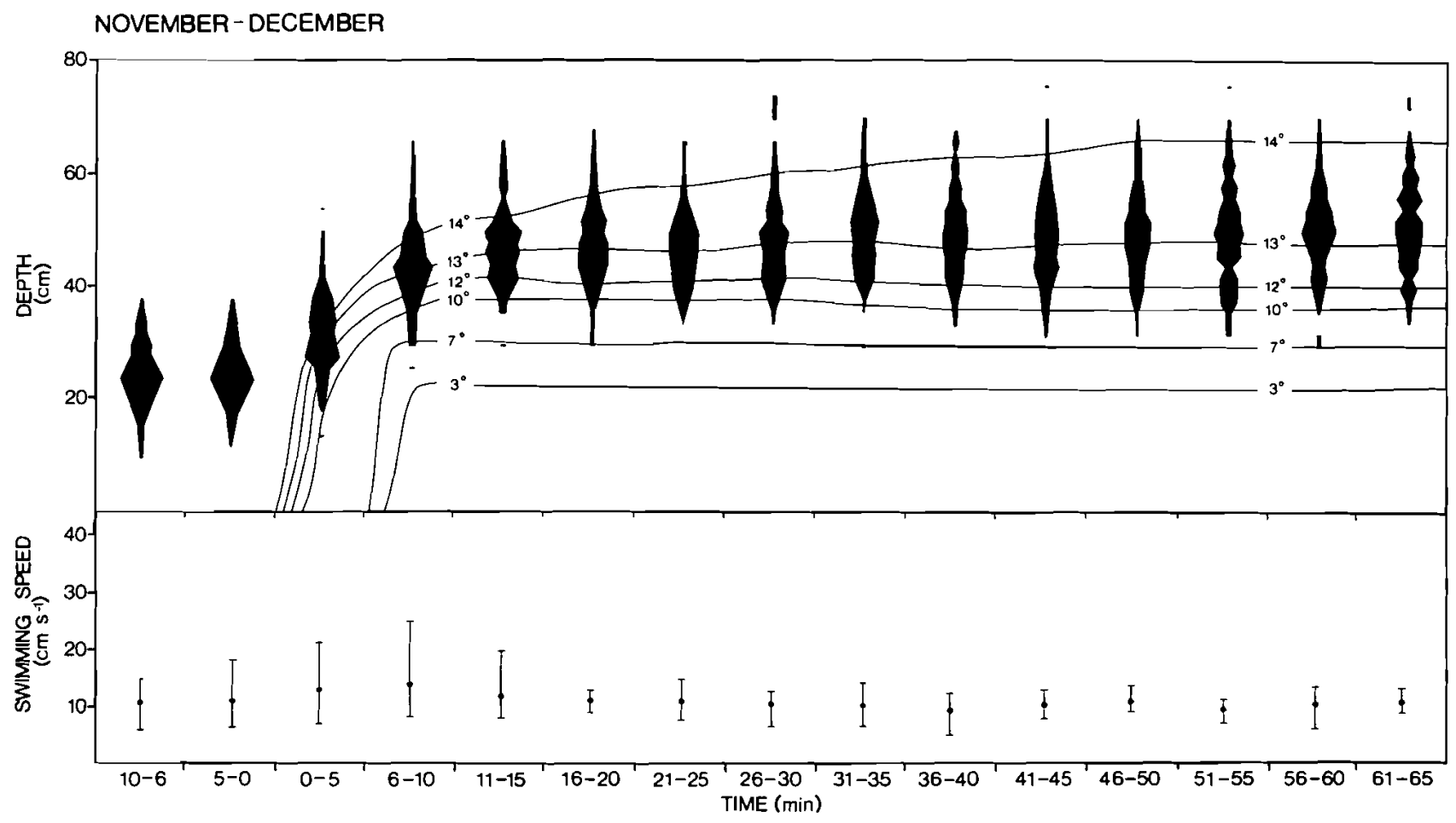

Fig. 5. Pomatomus saltatrix. Vertical distribution and swimming speed $\left(\overline{\mathbf{x}}, \mathrm{R}_{;} \mathrm{cm} \mathrm{s}^{-1}\right)$ of juveniles in vertical thermal gradients $\left({ }^{\circ} \mathrm{C}\right)$ in November-December following acclimation to $14^{\circ} \mathrm{C}$. Width of each distribution configuration represents number of fish at a given depth measured every $20 \mathrm{~s}$ within $5 \mathrm{~min}$ intervals. Data presented for $10 \mathrm{~min}$ prior to and 65 min following cold water introduction

resulted in ingestions, although the success rate (ingestions/attempts $\times 100$ ) tended to decrease from $100 \%$ at $6^{\circ} \mathrm{C}$ to $0 \%$ at $1^{\circ} \mathrm{C}$ (Fig. $6 \mathrm{~B}$ ). Occasionally a fish would sight food and swim downward as if to feed, but upon reaching colder water, would reverse direction and return to warmer temperatures. On other occasions, even after entering cold water to feed, a fish would occasionally snap at the food, attempting to ingest it, but would fail. In other instances, food ingested would be immediately expelled. While entering water cold enough to be potentially debilitating, the duration of exposure was $<1$ to $2 \mathrm{~s}$, far less than the time which would have caused a loss of orientation or equilibrium (Table 2).

Distribution in the gradient at $16^{\circ} \mathrm{C}$ and lower for the $10 \mathrm{~min}$ prior to food introduction was not significantly different $(P>0.05$; Wilcoxon Rank Sum Test) from that observed in the November experiments following $20^{\circ} \mathrm{C}$ acclimation. However, once food was introduced, the distribution of the fish, exclusive of their feeding excursions into cold water, was lower. Comparison with the previous November experiments for 11 through $35 \mathrm{~min}$ indicated a significant difference $(P<0.005$; Wilcoxon Rank Sum Test) in distribution at $16^{\circ} \mathrm{C}$ and below. Fish now spent $71.4 \%$ of the time at these temperatures as compared to $14.4 \%$ in November.

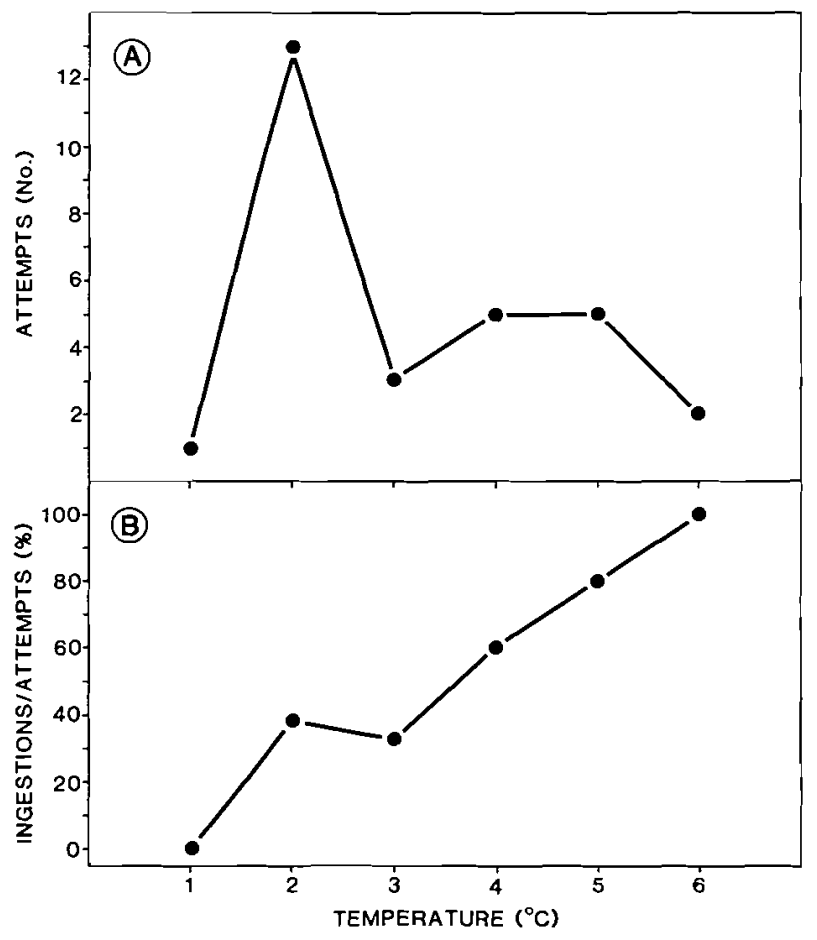

Fig. 6. Pomatomus saltatrix. (A) Attempts to capture food and (B) success rate (ingestions/attempts $\times 100$ ) of juveniles at 1 to $6{ }^{\circ} \mathrm{C}$ during the first 10 introductions of food in 7 feeding experiments in vertical thermal gradients 


\section{DISCUSSION}

Juvenile bluefish clearly demonstrated the capability for behavioral thermoregulation. This capability had been suggested by earlier studies in which both juveniles and adults exhibited increases in activity when exposed to changes in temperature under homeothermal conditions (Olla \& Studholme 1971. 1976, 1978, Olla et al. 1975, Olla 1977). In the present study, while changes in temperature also resulted in increased activity, once the thermal gradient had stabilized and the fish were able to avoid cold water, activity generally decreased. We surmised that the fish, by moving out of cold water, ceased to receive what Roberts (1979) referred to as 'aversive thermal feedback'. Then, although distributed predominantly in the warmer, upper reaches of the tank, the fish made downward excursions into cold water, engaging in exploratory behavior which enabled them to define spatially changing thermal boundaries, a process which was more or less continuous. These initial responses, which were not intended to represent the conventionally determined laboratory preferenda, are pertinent for a species which resides in inshore and estuarine environments in which temperatures can change very rapidly over short spans of time.

The influence of thermal history on thermal preferenda or resistance has been well established for most, if not all, species for which temperature responses have been studied (for examples and reviews see Fry 1967, 1971, Brett 1970, Fry \& Hochachka 1970). Also recognized, though less studied has been the influence of seasonal factors. One of the first demonstrations of the role that these factors may play was shown in studies by Hart (1952) in which differences in thermal tolerance of 4 fresh water species depended upon whether tests were conducted in summer or winter. In a similar vein. Tyler (1966) observed that thermal resistance of northern redbelly dace Chrosomus eos to upper lethal temperature varied from summer to winter, while Hoar \& Robertson (1959), studying goldfish Carassius auratus found resistance to abrupt thermal change regulated by seasonal photoperiod. Using metabolic measures, Roberts (1964) observed that responses of sunfish Lepomis gibbosus to changes in temperature were affected by photoperiod. In one of the few studies to examine the effect of season on behavioral responses, i.e. thermal selection, brook trout Salvelinus fontinalis exhibited seasonal changes in selected temperature independent of acclimation temperature (Sullivan \& Fisher 1953). More recently, the influence of season on behavioral responses was clearly demonstrated in laboratory studies on tautog Tautoga onitis (Olla et al. 1980). During the fall, at a time when this species normally migrates offshore to overwinter, changes in activity occurred under simulated seasonal changes in temperature and photoperiod which were indicative of migration. Under natural summer photoperiods however, when temperature was decreased, the fish exhibited only highly variable and transient components of migratory behavior.

The distribution of bluefish, with similar thermal history into progressively colder water from August through November, was a clear indication that changing photoperiod and/or associated factors play a major role in the response of this species to temperature. Our laboratory results are verified by what is known about the distribution of juvenile bluefish in nature with regard to season and temperature. In Sandy Hook Bay, as well as other areas of the Middle Atlantic Bight, juveniles may spend all or most of the summer in warm inshore or estuarine waters $\left(18\right.$ to $26^{\circ} \mathrm{C}$; Wilk \& Silverman 1976a, Olla unpubl.) before migrating southward in late fall (Lund \& Maltezos 1970). Based on samples of early juveniles collected prior to their recruitment onshore or into estuaries, Kendall \& Walford (1979) reported that the bulk of juveniles were found in June at temperatures $>18^{\circ} \mathrm{C}$ but by late October and early November, they were captured only south of the Middle Atlantic Bight at temperatures ranging from 15 to $17^{\circ} \mathrm{C}$. Similar correlations between temperature and distribution were observed for young-of-the-year bluefish collected from late spring through early November in trawl surveys along the Atlantic coast (Wilk \& Silverman 1976b). In the Black Sea, Oben (1957) observed that young bluefish came inshore in August at temperatures ranging from 18 to $24.5^{\circ} \mathrm{C}$ and began to depart in October when temperatures fell to 13 to $15^{\circ} \mathrm{C}$.

Photoperiod and/or other associated seasonal factors apparently act during the fall to predispose both adult and juvenile bluefish to tolerate cooler temperatures. This physiological adjustment may enhance the survival of the fish at a time when they can encounter precipitous drops in temperature. Furthermore, these factors may also act to trigger migration. Evidence for this can be seen when considering the yearly northward migration of adults from coastal waters of Florida in late winter and early spring (Wilk 1977, Kendall \& Walford 1979, Deuel unpubl.). In late January and early February when migration begins, ocean temperatures in this region do not change consistently upward or downward (Walford \& Wicklund 1968) and therefore are not likely to act as a stimulus for migration. A more likely factor would be changing photoperiod, a supposition which is supported by a laboratory study in which adult bluefish, exposed to seasonally changing photoperiod but under constant temperature, showed increases in activity which were corre- 
lated with changes in photoperiod coinciding with natural migratory periods (Olla \& Studholme 1972). In contrast, while photoperiod and temperature may also play dominant roles in the migratory behavior of tautog Tautoga onitis, a species whose summer range along the Atlantic coast overlaps that of bluefish, the role of temperature may be somewhat different (Olla et al. 1980). In the fall, under changing seasonal photoperiod but without a corresponding decrease in temperature, migratory behavior is not triggered.

While temperature may not be the primary stimulus for long distance migration in bluefish, our results, as well as the correlation between catch statistics of adults and temperature (Wilk \& Silverman 1976b, Walford \& Wicklund unpubl.), suggest that distribution is influenced by temperature. However, temperature data do not necessarily predict where a species will occur as much as indicate areas from which it will be excluded because of physiological or behavioral thermal limits. Within thermal limits fish may distribute themselves on the basis of ecological factors other than temperature so that their absence in the natural environment at laboratory-determined 'preferred' temperatures may be explained by the lack of one or more of these factors, with food availability being especially critical. Thus, we would expect that, to a large degree, fish regulate their distribution so as to optimize growth and fitness within the bioenergetic constraints imposed by temperature and food availability (Brett 1971, Crowder \& Magnuson 1983). However, the degree to which even these can be optimized depends upon the presence of other critical requirements, e.g. shelter availability (Olla et al. 1980).

With regard to thermal limits, certain hydrographic features, such as changing thermal gradients, cold cells like that found off the Middle Atlantic coast in late spring and summer (Ketchum \& Corwin 1964, Ingham et al. 1982) or frontal systems, such as those found along Cape Hatteras (Magnuson et al. 1980. 1981, Brandt \& Wadley 1981), may act as barriers to species such as bluefish. Along the Cape Hatteras frontal systems, bluefish are found at temperatures ranging from about 15 to $23^{\circ} \mathrm{C}$ (Magnuson et al. 1980). With a variety of prey species gathered on both sides of these fronts, the capability for bluefish to forage, even for brief intervals at temperatures beyond their thermal tolerance, would be highly advantageous. In our feeding experiments, where food was available at temperatures which were potentially debilitating and which were normally avoided except for exploratory excursions, juveniles were capable of successfully ingesting food and returning to warmer water within seconds without functional impairment. With the latency for thermal effects a function of the cooling rate of a fish and therefore dependent upon body size (Stevens \&
Fry 1970, 1974, Spigarelli et al. 1974, 1977, Beitinger et al. 1977), juveniles which ranged from about 40 to $100 \mathrm{~g}$ and acclimated to $14^{\circ} \mathrm{C}$ lost equilibrium at $5^{\circ} \mathrm{C}$ within $1.1 \mathrm{~min}$. Since thermal effects are also related to seasonal factors, this probably reflects their maximum ability to withstand low temperatures because these tests were conducted in January. Adult fish, weighing about $4 \mathrm{~kg}$, took as long as $29 \mathrm{~min}$ for a similar loss of equilibrium when transferred from 14 to $5^{\circ} \mathrm{C}$ (Olla \& Bejda unpubl.). It is possible therefore that as long as temperature was available within tolerance limits, adult fish could forage at temperatures beyond these limits.

It is apparent from our laboratory studies that decisions as to how long to remain at these temperatures are well within the capability of the species. Not all species, however, appear to have the capability to make such decisions successfully. Under one experimental paradigm in which food was available to yellow perch Perca flavescens only at non-preferred temperatures, death apparently occurred when exposure to temperature above their upper lethal level was prolonged (Neill \& Magnuson 1974). In another laboratory study, juvenile rainbow trout Salmo gairdneri conditioned to enter high temperatures to obtain food, did so, even when temperature became so extreme as to cause 50 to $60 \%$ mortality in some groups (Munson et al. 1980).

Acknowledgements. We express our thanks to Carol Samet for help throughout all phases of the study and to Michele Cox for preparation of the figures.

\section{LITERATURE CITED}

Beitinger, T. L., Thommes, M. M., Spigarelli, S. A. (1977). Relative roles of conduction and convection in the body temperature change of gizzard shad, Dorosoma epedianum. Comp. Biochem. Physiol. 57A: 275-279

Brandt, S. B., Magnuson, J. J., Crowder, L. B. (1980). Thermal habitat partitioning by fishes in Lake Michigan. Can. J. Fish. aquat. Sci. 37: 1557-1564

Brandt, S. B., Wadley, V. A. (1981). Thermal fronts as ecotones and zoogeographic barriers in marine and freshwater systems. Proc. Ecol. Soc. Aust. 11: 13-26

Brett, J. R. (1970). Temperature: animals: fishes. In: Kinne, O. (ed.) Marine ecology, Vol. l, Environmental factors, Pt. 1. Wiley \& Sons, Ltd., London, p. 515-560

Brett, J. R. (1971). Energetic responses of salmon to temperature. A study of some thermal relations in the physiology and freshwater ecology of sockeye salmon (Oncorhynchus nerka). Am. Zool. 11: 99-113

Crowder, L. B., Magnuson, J. J. (1982). Thermal habitat shifts by fishes at the thermocline in Lake Michigan. Can. J. Fish. aquat. Sci. 39: 1046-1050

Crowder, L. B., Magnuson, J. J. (1983). Cost-benefit analysis of temperature and food resource use: a synthesis with examples from the fishes. In: Aspey, W. P., Lustick, S. I. 
(ed.) Behavioral energetics. Ohio State Univ. Press, Columbus, Ohio, p. 189-221

Fry, F. E. J. (1947). Effects of the environment on animal activity. Univ. Toronto Stud. biol. Ser. 55: 1-62

Fry, F. E. J. (1967). Responses of vertebrate poikilotherms to temperature. In: Rose, A. H. (ed.) Thermobiology. Academic Press, London, p. 375-409

Fry, F. E. J. (1971). The effect of environmental factors on the physiology of fish. In: Hoar, W. S., Randall, D. J. (ed.) Fish physiology, Vol. VI, Environmental relations and behavior. Academic Press, New York, p. 1-98

Fry, F. E. J., Hochachka, P. W. (1970). Fish. In: Whittow, G. C. (ed.) Comparative physiology of thermoregulation, Vol. $\mathrm{l}_{\text {, }}$ Invertebrates and nonmammalian vertebrates. Academic Press, New York, p. 79-134

Garside, E. T., Morrison, G. C. (1977). Thermal preferences of mummichog, Fundulus heteroclitus L., and banded killifish, $F$. diaphanus (Le Sueur), (Cyprinodontidae) in relation to thermal acclimation and salinity. Can. J. Zool. 55: 1190-1194

Hart, J. S. (1952). Geographic variations of some physiological and morphological characters in certain freshwater fish. Univ. Toronto Stud. biol. Ser. 60: 1-79

Hoar, W. S., Robertson, G. B. (1959). Temperature resistance of goldfish maintained under controlled photoperiods. Can. J. Zool. 37: 419-428

Ingham, M. C. (ed.), Armstrong, R. S., Chamberlin, J. L., Cook, S. K., Mountain, D. G., Schlitz, R. J., Thomas, J. P., Bisagni, J. J., Paul, J. F., Warsh, C. E. (1982). Summary of the physical oceanographic processes and features pertinent to pollution distribution in the coastal and offshore waters of the northeastern United States, Virginia to Maine. NOAA Tech. Memo. NMFS-F/NEC-17: 49-60

Javaid, M. Y., Anderson, J. M. (1967). Influence of starvation on selected temperature of some salmonids. J. Fish. Res. Bd Can. 24: 1515-1519

Kendall, A. W., Jr., Walford, L. A. (1979). Sources and distribution of bluefish, Pomatomus saltatrix, larvae and juveniles off the east coast of the United States. Fish. Bull. U.S. 77: 213-227

Ketchum, B. H., Corwin, N. (1964). The persistence of 'winter' water on the continental shelf south of Long lsland, New York. Limnol. Oceanogr. 9: 467-475

Kwain, W., McCauley, R. W. (1978). Effects of age and overhead illumination on temperatures preferred by underyearling rainbow trout, Salmo gairdneri, in a vertical temperature gradient. J. Fish. Res. Bd Can. 35: 1430-1433

Lund, W. A., Jr., Maltezos, G. C. (1970). Movements and migrations of the bluefish, Pomatomus saltatrix, tagged in waters of New York and southern New England. Trans. Am Fish. Soc. 99: 719-725

Magnuson, J. J., Brandt, S. B., Stewart, D. J. (1980). Habitat preferences and fishery oceanography. In: Bardach, J. E., Magnuson, J. J., May, R. C., Reinhart, J. M. (ed.) Fish behavior and its use in the capture and culture of fishes. ICLARM Conf. Proc. 5, International Center for Living Aquatic Resources Management, Manila, p. 371-382

Magnuson, J. J., Harrington, C. L., Stewart, D. J., Herbst, G. H. (1981). Responses of macrofauna to short-term dynamics of a Gulf Stream front on the continental shelf. In: Richards, F. A. (ed.) Coastal and estuarine science, 1, Coastal upwelling. American Geophysical Union, Washington, D. C., p. 441-448

McCauley, R. W., Read, L. A. A. (1973). Temperature selection by juvenile and adult yellow perch (Perca flavescens) acclimated to $24^{\circ} \mathrm{C}$. J. Fish. Res. Bd Can. 30: 1253-1255

Medvick, P. A., Magnuson, J. J., Sharr, S. (1981). Behavioral thermoregulation and social interactions of bluegills, Lepomis macrochirus. Copeia 1981: 9-13

Medvick, P. A., Miller, J. M. (1979). Behavioral thermoregulation in three Hawaiian reef fishes. Environ. Biol. Fish. 4: $23-28$

Munson, B. H., McCormick, J. H., Collins, H. L. (1980). Influence of thermal challenge on conditioned feeding forays of juvenile rainbow trout. Trans. Am. Fish. Soc. 109: $116-121$

Neill, W. H., Magnuson, J. J. (1974). Distributional ecology and behavioral thermoregulation of fishes in relation to heated effluent from a power plant at Lake Monona, Wisconsin. Trans. Am. Fish. Soc. 103: 663-710

Neill, W. H., Magnuson, J. J., Chipman, G. (1972). Behavioral thermoregulation by fishes: a new experimental approach. Science, 176: 1443-1445

Norcross, J. J., Richardson, S. L., Massmann, W. H., Joseph, E. B. (1974). Development of young bluefish (Pomatomus saltatrix) and distribution of eggs and young in Virginian coastal waters. Trans. Am. Fish. Soc. 103: 477-497

Oben, L. C. (1957). About the drifting approach of fingerling bluefish Pomatomus saltatrix (Linnaeus) to the shores of the Black Sea in the region of the Karadag (1947-1954). Karadag Biol. Stn. Acad. Sci. Ukr. USSR 14: 155-157 (Translated by M. J. Koushnaroff and R. J. Mansueti)

Olla, B. L. (1977). The effect of low temperature on the activity of juvenile bluefish, Pomatomus saltatrix. Progress Report, Energy Research and Development Administration (unpubl.)

Olla, B. L., Studholme, A. L. (1971). The effect of temperature on the activity of bluefish, Pomatomus saltatrix L. Biol. Bull. mar. biol. Lab., Woods Hole 141: 337-349

Olla, B. L., Studholme, A. L. (1972). Daily and seasonal rhythms of activity in the bluefish (Pomatomus saltatrix). In: Winn, H. E., Olla, B. L. (ed.) Behavior of marine animals: current perspectives in research, Vol. 2, Vertebrates. Plenum Press, New York, p. 303-326

Olla, B. L., Studholme, A. L. (1976). Environmental stress and behavior: response capabilities of marine fishes. In: Second joint U.S./USSR symposium on the comprehensive analysis of the environment. Environmental Protection Agency, Washington, D. C., p. 25-31

Olla, B. L., Studholme, A. L. (1978). Comparative aspects of the activity rhythms of tautog, Tautoga onitis, bluefish, Pomatomus saltatrix and Atlantic mackerel, Scomber scombrus, as related to their life habits. In: Thorpe, J. E. (ed.) Rhythmic activity of fishes. Academic Press, London, p. 131-151

Olla, B. L., Studholme, A. L., Bejda, A. J., Samet, C. (1980). Role of temperature in triggering migratory behavior of the adult tautog Tautoga onitis under laboratory conditions. Mar. Biol. 59: 23-30

Olla, B. L., Studholme, A. L., Bejda, A. J., Samet, C., Martin, A. D. (1975). The effect of temperature on the behaviour of marine fishes: a comparison among Atlantic mackerel, Scomber scombus, bluefish, Pomatomus saltatrix, and tautog, Tautoga onitis. In: Combined effects of radioactive, chemical and thermal releases to the environment. IAEA SM-197/4. International Atomic Energy Agency, Vienna, p. 299-308

Olla, B. L., Studholme, A. L., Bejda, A. J., Samet, C., Martin, A. D. (1978). Effect of temperature on activity and social behavior of the adult tautog Tautoga onitis under laboratory conditions. Mar. Biol. 45: 369-378

Reynolds, W. W., Casterlin, M. E., Covert, J. B. (1976). Behavioural fever in teleost fishes. Nature, Lond. 259: 41

Roberts, J. L. (1964). Metabolic responses of fresh-water sun- 
fish to seasonal photoperiods and temperatures. Helgoländer wiss. Meeresunters. 9: 459-473

Roberts, J. L. (1979). Seasonal modulation of thermal acclimation and behavioral thermoregulation in aquatic animals. In: Vernberg, W. B., Calabrese, A., Thurberg, F. P., Vernberg, F. J. (ed.) Marine pollution: functional responses. Academic Press, New York, p. 365-388

Rozin, P. N., Meyer, J. (1961). Thermal reinforcement and thermoregulatory behavior in the goldfish, Carassius auratus. Science, 134: 942-943

Spigarelli, S. A., Romberg, G. P., Prepejchal, W., Thommes, M. M. (1974). Body-temperature characteristics of fish at a thermal discharge on Lake Michigan. In: Gibbons, J. W., Sharitz, R. R. (ed.) Thermal ecology. AEC Symposium Series CONF-730505, p. 119-132

Spigarelli, S. A., Thommes, M. M., Beitinger, T. L. (1977). The influence of body weight on heating and cooling of selected Lake Michigan fishes. Comp. Biochem. Physiol. 56 A: 51-57

Stevens, E. D., Fry, F. E. J. (1970). The rate of thermal exchange in a teleost, Tilapia mossambica. Can. J. Zool. 48: 221-226

Stevens, E. D., Fry, F. E. J. (1974). Heat transfer and body temperatures in non-thermoregulatory teleosts. Can. J. Zool. 52: 1137-1143
Stuntz, W. E., Magnuson, J. J. (1976). Daily ration, temperature selection, and activity of bluegill. In: Esch, G. W., McFarlane, R. W. (ed.) Thermal ecology 2. Technical Information Center, Energy Research and Development Administration, Washington, D. C., p. 180-184

Sullivan, C. M., Fisher, K. C. (1953). Seasonal fluctuations in the selected temperature of speckled trout, Salvelinus fontinalis (Mitchill). J. Fish. Res. Bd Can. 10: 187-195

Tyler, A. V. (1966). Some lethal temperature relations of two minnows of the genus Chrosomus. Can. J. Zool. 44: 349-364

Walford, L. A., Wicklund, R. I. (1968). Monthly sea temperature structure from the Florida Keys to Cape Cod. In: Webster, W. (ed.) Serial Atlas Mar. Environ., Folio 15. American Geographical Society, New York

Wilk, S. J. (1977). Biological and fisheries data on bluefish, Pomatomus saltatrix (Linnaeus). Sandy Hook Lab. Tech. Ser. Rep. 11

Wilk, S. J., Silverman, M. J. (1976a). Summer benthic fish fauna of Sandy Hook Bay, New Jersey. NOAA Tech. Rep. NMFS SSRF-698

Wilk, S. J., Silverman, M. J. (1976b). Fish and hydrographic collections made by the research vessels Dolphin and Delaware II during 1968-72 from New York to Florida. NOAA Tech. Rep. NMFS SSRF-697

This paper was presented by Dr. R. Lasker; it was accepted for printing on February 1, 1985 